\title{
RESILIENSI PANCASILA DI ERA DISRUPSI: DILEMATIS MEDIA SOSIAL DALAM MENJAWAB TANTANGAN ISU INTOLERANSI
}

\author{
Hendri Irawan ${ }^{1}$, Krisbaya Bayu Firdaus ${ }^{2}$ \\ Universitas Negeri Semarang \\ Jalan Tamansiswa, Sekaran, Gunungpati, Kota Semarang, Jawa Tegah, 50229 \\ hendriirawan668@gmail.com ${ }^{1}$, krisbaya24@students.unnes.ac.id ${ }^{2}$.
}

\begin{abstract}
Abstrak:
Keberagaman adalah suatu keniscayaan yang tidak bisa ditolak oleh manusia, dalam hal ini adalah masyarakat Indonesia, keberagaman akan memberikan dampak positif. Namun, tidak sedikit adanya keberagaman akan menimbulkan dampak negatif yakni konflik yang ada di masyarakat salah satunya adalah terkait intolernasi. Untuk menyelesaikan masalah tersebut pada dasarnya dapat dikembalikan lagi ke dasar negara Republik Indonesia yakni Pancasila. Namun, dengan perkembangan jaman memasuki era disrupsi, artinya perubahan yang semakin cepat dan tidak bisa dikontrol akan berdampak pada ideologi itu sendiri. Memasuki era disrupsi ditandai dengan sala satunya adanya media sosial. Namun, media sosial memiliki dilematis yang luar biasa artinya dapat menjadi alat pemersatu dan meneguhkan nilai-nilai pancasila tapi bisa saja sebaliknya. Tantangan itu lah yang menjadikan seberapa tangguh pancasila dalam menghadapi persoalan tersebut. Tujuan dalam penelitian ini adalah untuk menganalisis ketangguhan pancasila dalam menghadapi isu intoleransi dan untuk menganalisis dampak dari segi peluang dan tantangan dengan adanya pancasila untuk menjawab isu intoleransi. Metode yang digunakan dalam penulisan ini adalah deskriptif kualitatif yang menggunakan data sekunder dari sumber berupa jurnal,artikel dan foto yang terkait. Hasil penulisan ini adalah Perkembangan era disrupsi yang ditandai dengan adanya media sosial. Bahwasannya media sosial memiliki dua dampak yakn positif dan negatif, hal tersebut adalah menjadi suatu dilematis dalam menjawab isu-isu toleransi. Media sosial dapat menjadi sumber perpecahan yang akan mengancam ideologi pancasila, tapi sebaliknya dapat menjadi alat atau media
\end{abstract}

\section{Paris Langkis}

Vol.1 Nomor 2, Maret 2021 
untuk menciptakan integrasi dalam masyarakat. Kurang optimalnya peran pemerintah. Maka dari itu pemerintah perlu berperan lebih dan melibatkan juga masyarakat untuk menyelesaikan masalah intoleransi. Apabila tidak maka hadirnya media sosial justru menjadi ancaman bagi ideologi bangsa Indonesia karena tidak memiliki resiliensi atau kekuatan.

Kata Kunci: Dilematis, Media Sosial,Pancasila, Resiliensi, dan Toleransi

\section{A. PENDAHULUAN}

Indonesia adalah negara yang beragam, Indonesia lahir bukan hanya dari satu latar belakang, melainkan berbagai macam latar belakang. Keberagaman yang ada di Indonesia adalah suatu keniscayaan yang diberikan oleh Tuhan. Hal tersebut mengakibatkan bahwa Indonesia adalah negara yang multikultural. Menurut Parekh (2010) mengemukakan bahwa multikultural bukanlah doktrin politik pragmatis, melainkan sebuah cara padang dalam kehidupan manusia, dikatakan bahwa esensi mendasar tentang perilaku multikulturalisme adalah saling mengerti dan saling memahami antar sesama dilingkungan yang beragam atau majemuk.

Masyarakat adalah suatu kelompok yang mudah di mobilisasi oleh suatu kepentingan yang cenderung memecah belah mereka salah satunya mengangkat isu primordialisme yang terbukti dapat menjadi alat untuk mendisintegrasikan kehidupan dalam masyarakat. Hal tersebut sering menimbulkan adanya suatu perpecahan atau konflik dalam masyarakat Indonesia. Keragaman masyarakat multikultural sebagai kekayaan bangsa di sisi lain sangat rawan memicu konflik dan perpecahan (Lestari, dalam Fathurofik 2020).Keberagaman yang dimiliki oleh Indonesia dapat dijadikan kelebihan untuk kita, jika bisa memanfaatkan dengan bijak, hanya saja akan berbadning terbalik jika kurang tepat dalam menanggapi keberagaman tersebut. Dari ujung barat sampai ujung timur banyak sekali keberagaman yang dapat ditemukan, dari suku, ras, etnis, budaya, agama dan lain sebagainya. Sudah tidak asing lagi jika Indonesia dikenal di luar negeri sebagai negara yang beragam.

Menurut Abdusammi (dalam Utami, 2018: 3) Keberagaman (pluralitas) adalah sebuah kenyataan hidup dimana setiap orang harus berusaha sampai kepada sikap saling memahami satu sama lain. Perlu diingat bahwa kekayaan keberagaman yang dimiliki Indonesia bagaikan mata pisau, jika tidak bijak maka justru akan menghancurkan, namun jika ditanggapi dengan bijak maka menjadi keistimewaan negara ini. $\mathrm{Ha}$ tersebut menjadikan adanya keberagaman akan memiliki dua dampak yakni positif dan negatif. Dampak negatif yang sering muncul terkait keberagaman adalah dapat meningkatkan rasa intoleransi dan konflik, contohnya konflik antara suku Dayak dan suku Madura yang terjadi di Sampit, Kalimantan tengah yang berkembang menjadi konflik antar etnis taun 2011 (Mahfud, dalam Fathurofik 20202) selanjutnya kerusuhan Ambon antar masyarakat beragama kristen dan islam tahun 1998, konflik di Poso tahun 1998-2001, kerusuhan talikora di Papua tahun 2015,

\section{Paris Langkis}

Vol.1 Nomor 2, Maret 2021 
dan kasus pembekaran gereja di Aceh Singkil tahun 2015 (Harahap, dalam Fathurofik 2020), PILKADA di Jakarta, bahkan kasus- intoleransi mulai nampak di lingkungan sekolah, sekolah yang seharusnya menjadi tempat untuk memupuk toleransi malah sebaliknya. Diatas yang telah disebutkan adalah salah satu contoh kecil dari efek negatif adanya keberagaman. Kemudian dampak positifnya adalah dengan adanya keberagaman, maka masyarakat memiliki kepedulian, dapat meningkatkan kerjasama, hal demikian akan mengakibatkan muncul rasa toleransi di masyarakat.

Menurut Kamus Besar Bahasa Indonesia, toleransi berasal dari kata "toleran” yang bersifat atau bersikap menengang (menghargai, membiarkan, membolehkan), pendirian (pendapat, pandangan, kepercayaan, kebiasaan dan sebagainya) yang berbeda dan atau yang bertentangan dengan pendiriannya (Depdiknas, 2008). Toleransi disini bukan hanya dari aspek keagamaan saja, melainkan sangat luas, baik dari segi sosial, ekonomi, budaya, suku, ras dan kehidupan bermasyarakat pada umumnya. Jika ditarik kebelakang, pada hakikatnya bahwa Indonesia sudah sangat menyadari risiko yang akan muncul dari adanya keberagaman ini. Bahkan bisa dikatakan semangat juang untuk meredeka lahir karena adanya perbedaan. Maka, dari itu atas kesadaran tersebut bahwasanya Indonesia sudah memiliki alat agar keberagaman yang dimiiki oleh Indonesia akan tetap terjaga sampai kapan pun yakni melalui Pancasia. Pancasila adalah ideologi dan dasar negara kesatuan republik Indonesia sebagaimana yang termaktub dalam alenia keempat pembukaan UUD 1945.

Pancasila memiliki nilai yang digali dari Indonesia, artinya digali dan diambil dari kekayaan, rohani, moral dan budaya masyarakat dan bangsa Indonesia. Di sini Pancasila dikenal sebagai Ideologi terbuka dalam arti bahwa,Pancasila sebagai Ideologi yang mampu mengikuti perkembangan jaman serta dinamis, merupakansistem pemikiran terbuka dan merupakan hasilkonsensus masyarakat itu sendiri, oleh karena itu Pancasila juga merupakan dasar negara yangsudah barang tentu harus terwujud dalam segalaaspek kehidupan berbangsa dan bernegara.Pancasila hadir diharapkan menjadi suatu dasar atau landasan dalam berkehidupan dan menjawab segala tantangan apalagi di era sekarang seperti saat ini.

Perkembangan jaman yang terus berjalan hal tersebut mendorong memasuki era disrupsi, di era disrupsi menjadi tantangan sendiri bagi ideoogi negara Indonesia yakni pancasia. Era disrupsi dapat diartikan sebagai perubahan fundamental sehingga dapat mengubah tatanan kehidupan manusia dari berbagai segi. Rhenald Kasali dalam bukunya berjudul Disruption (2014), menjelaskan; Perubahan yang terjadi diawali dengan hal kecil, sedemikian kecil sehingga terabaikan oleh mereka yang besar. Perubahan itu bahkan tidak terlihat, dan tiba - tiba begitu besar. Inilah karakter perubahan pada abad ke-21: cepat, mengejutkan, memindahkan (Azhar, 2018). Era disrupsi akan mempengaruhi semua aspek salah satu diantaranya adalah lingkungan, sosial, ekonomi, budaya, dan teknologi.

\section{Paris Langkis}

Vol.1 Nomor 2, Maret 2021 
Fenomena ini pun tentunya didukung karena munculnya teknologi digital yang memudahkan aktivitas masyarakat. Memasuki era disrupsi ditandai dengan perkembangan teknologi yang semakin cepat salah satunya adalah adanya penggunaan media sosial. Media sosial menjadikan platform yang digemari oleh masyarakat Indonesia. Perkembangan penggunaan media sosial terus mengalami peningkatan. Berdasarkan hasil riset yang dilakukan oleh Hootsuite (We are Social): Indonesian Digital Report 2020 bahwa pengguna media sosial sebanyak 160 juta orang. Di era disrupsi ini yang semakin berubah cepat saah satunya penggun media sosial terus mengalami peningkatan, namun ada juga dampak yang ditimbulkan dari adanya media sosial yakni dampak negatif dan dampak positif. Tapi, yang di soroti dalam penulisan ini adalah dampak negatif dari penggunaan media sosial.

Seperti dijelaskan sebelumnya bahwasannya pancasila adalah ideologi yang bersifat terbuka artinya pancasila sebagai Ideologi yang mampu mengikuti perkembangan jaman serta dinamis. Namun, belakangan ini seakan eksistensi pancasila di era saat ini seakan diuji melalui berbagai media salah satunya adalah media sosial. Padahal seharusnya dengan adanya perkembangan jaman dan teknologi yang ditandai dengan adanya media sosial dapat dimanfaatkan agar ideologi pancasila semakin kuat di masyarakat. Dilematis perkembangan media sosial akan berdampak pada kehidupan masyarakat salah satunya adalah isu toleransi. Berita yang beredar di media sosial terkait intoleransi seakan menjadi boomerang bagi ideologi pancasila, apalagi berkembangnya berita-berita yang belum tentu kebenarannya atau yang biasa disebut berita hoaxselain itu juga terkait perdebatan di media sosial itu sendiri.

Memasuki era disrupsi yang ditandai dengan perkembangan media sosial akan menjadi sebuah dilematis bagi pancasila itu sendiri, yang memiliki arti seperti mata pisau, dapat bermanfaat atau sebaliknya. Kekuatan pancasila di era disrupsi semakin diuji seberapa bertahannya ideologi tersebut dalam mengatasi masalah-masalah intoleransi khususnya yang bersumber dari media sosial, media sosial dapat menjawab serta menjebatani untuk meningkatkan rasa toleransi atau malah sebaliknya yakni menjadi faktor untama timbulnya rasa intoleransi di masyarakat. Dari latar beakang tersebut maka dari itu judul dalam paper ini adalah "Resiliensi Pancasila di Era Disrupsi: Dilematis Media Sosial dalam Menjawab Tantangan Isu Toleransi”. Tujuan dari penulisan ini adalah menganalisis potensi kekuatan pancasila melalui dilematis media sosial dalam menjawab tantangan isu toleransi.

\section{B. METODE PENELITIAN}

Penelitian ini menggunakan metode penelitian kualitatif. Metode penelitian kualitatif ini digunakan sebagai prosedur penelitian yang menghasilkan data deskriptif berupa kata-kata tertulis atau lisan dari orangorang yang diamati. Kirkl dan Miller dalam (Moleong, 2010:4) mendefinisikan bahwa penelitian kualitatif adalah tradisi tertentu dalam ilmu pengetahuan sosial yang secara fundamental bergantung dari pengamatan pada manusia

\section{Paris Langkis}

Vol.1 Nomor 2, Maret 2021 
baik dalam kawasannya maupun dalam peristilahannya. Sedangkan menurut Bogdan dan Taylor (dalam Moleong, 2005:3), metode penulisan kualitatif sebagai suatu prosedur penelitian yang menghasilkan data deskriptif, yaitu kata-kata tertulis atau lisan dari orang-orang dan perilaku yang diamati. Penelitian ini menggunakan kualitatif deskriptif.

Fokus penelitian dalam penelitian kualitatif lebih didasarkan pada tingkat kepentingan, urgensi dan fasebilitas masalah yang akan dipecahkan, selain juga faktor keterbatasan tenaga, dana dan waktu (Sugiyono, 2016: 286). Pada penelitian ini yang difokuskan pada terkait analisis resiliensi pancasila di era disrupsi dan peluang dan tantangan media sosial dalam menjawab isu toleransi.Kemudian, sumber data, Menurut Lofland dalam Lexy J. Moloeng (2007:157) sumber data utama dalam penelitian kualitatif adalah kata-kata dan tindakan selebihnya ialah data tambahan seperti dokumen dan lainnya. Berkaitan dengan hal itu pada bagian ini jenis datanya dibagi kedalam katakata dan tindakan, sumber data tertulis, foto dan statistik. Sumber data yang digunakan dalam penulisan ini adalah data sekunder.

Data sekunder merupakan data pelengkap yaitu berfungsi melengkapi data yang diperlukan oleh data primer. Dilihat dari segi sumber data, bahan tambahan yang berasal dari sumber tertulis dapat dibagi atas sumber buku dan majalah ilmiah, sumber dan arsip, dokumen pribadi, dan dokumenresmi (Maleong, 2011:159). Pada penelitian ini yang dapat digolongkan ke dalam data sekunder meliputi dokumen, jurnal atau artikel, dan foto yang sesuai dengan topik atau fokus penulisan. Buku literatur, dokumen penelitian sebelumnya yang berupa hasil penelitian sebelumnya.

\section{PEMBAHASAN}

\section{Pancasila sebagai Dasar Negara}

Bangsa dimanapun untuk bertahan dan mengetahui dengan jelas arah tujuan dan cita-cita maka perlunya suatu landasan (filsafat). Tanpa memiliki kejelasan cita-cita atau pandangan hidup maka suatu bangsa akan merasa terombang-ambing dalam menghadapi persoalan yang terjadi dalam masyarakat. Hadirnya pandangan hidup yang dimiliki oleh suatu bangsa maka dapat menjadi pedoman atau pegangan dalam menyelesaikan berbagai permasalahan. Salah satu bangsa yang memilikiny adalah Indonesia, ideologi atau pandangan hidup yang dimiliki oleh bangsa Indonesia adalah pancasila.

Pancasila merupakan pandangan hidup, kesadaran dan cita-cita, moral yang meliputi kejiwaan dan watak yang sudah berakar di dalam kebudayaan Indonesia. Pancasila sebagai sistem filsafat adalah berlandaskan pada hakekat kodrat manusia, walaupun semula tidak terpikirkan oleh tokohtokoh kenegaraan Indonesia tentang hakekat kodrat manusia, namun karena betul-betul hasil dari perenungannya yang mendalam maka secara langsung dijiwai oleh manusia dalam hidup bersama (landasan ontologis pancasila).

\section{Paris Langkis}

Vol.1 Nomor 2, Maret 2021 
Permasalahan yang terus terjadi sampai saat ini adalah suatu ujian dan cobaan bagi Indonesia seberapa tangguh dan kuat ideologi pancasila ini, khususnya dalam menangani masalah intoleransi. Lahirnya pancasila adalah karena adanya keberagaman yang terjadi di masyarakat saat itu. Tapi, dengan perkembangan era justru malah sebaliknya, Pancasila diharapkan menjadi solusi dalam menangani masalah keberagaman khususnya intoleransi.

\section{Resiliensi Pancasila di Era Disrupsi}

Menurut Moberg dan Simonsen, "Resilience is the capacity of a system, be it an individual, a forest, a city or an economy, to deal with change and continue to develop. It is about the capacity to use shocks and disturbances like a financial crises or climate change to spur renewal and innovative thinking" dari definisi tersebut memberi penekanan pada kapasitas atau kemampuan sebuah sistem untuk mengatasi masalah, tidak membedakan dimensi apa dari sistem tersebut. Atas dasar itu, maka dari perspektif sosiologi, resiliensi sosial dapat didefinisikan sebagai kemampuan suatu sistem sosial untuk mempertahankan keutuhan atau integrasi sosialnya, pada saat dan/atau setelah mendapat gangguan, baik dari dalam maupun dari luar.

Selanjutnya arti dari resiliensi pancasila di era disrupsi adalah saat ini perubahan yang semakin cepat dan tidak bisa dikontrol dan sudah barang tentu akan memberikan dampak pada ideologi pancasila itu sendiri dalam hal ini adalah munculnya kasus intoleransi, hal tersebut dapat mengakibatkan kegoyahan hakikat pancasila itu sendiri. Nilai dalam pancasila dari sila pertama sampai sila kelima sudah jelas akan terkena dampaknya. Jika hal itu terjadi tanpa adanya kekuatan maka bisa jadi ideologi pancasila akan diganti. Dari situlah peran kekuatan pancasila dan seberapa kuat pancasila dalam menangani persoalan terkait intoleransi. Kemudian, apa yang terjadi media sosial saat ini akan memiliki dilematis apakah bisa menjadi alat untuk menguatakan atau justru sebaliknya.

\section{Dilematis Media Sosial dalam Menjawab Tantangan Isu Toleransi}

Memasuki era disrupsi yanng ditandai dengan perkembangan teknologi yang semakin maju, salah satunya lahirnya media sosial. Sosial media adalah sebuah media untuk bersosialisasi satu sama lain dan dilakukan secara online yang memungkinkan manusia untuk saling berinteraksi tanpa dibatasi ruang dan waktu. Media sosial menghapus batasan manusia untuk berinteraksi, hadirnya media sosial akan memberikan dampak bagi kehidupan manusia salah satu diantaranya adalah munculnya berita-berita hoax yang khususnya terkait intoleransi hal tersebut akan mengancam ideologi pancasila.

Berdasarkan hasil survei yang dilakukan oleh INFID dan Jaringan Gusdurian bahwa menyebarkan sikap intoleransi akan mengancam keberagaman bangsa Indonesia. Hasil penelitian yang dilakukan International NGO Forum on Indonesia Development, pertama, pengamatan

\section{Paris Langkis}

Vol.1 Nomor 2, Maret 2021 
terhadap situs-situs online (yang dianggap) radikal; dan kedua, pengamatan terhadap percakapan di media sosial. Proses pencarian data berdasar kata kunci yang dirumuskan lewat indikator untuk mengawasi ekstremisme oleh The International Centre for Counter-Terrorism (ICCT), yang berbasis di Den Haag. ICCT memiliki ribuan kata yang masuk kategori radika dan ekstrim kurang lebih 25 kata kunci (https://tirto.id).

Selain itu berdasakan hasil riset ada beberapa akun media sosial yang sekiranya mengandung pesan-pesan radikal dan ekstrimisme Kemudian berdasarkan dari penelitian yang sama ada 20 akun Twitter paling sering mencuit dan mengicau-balik (retweet) pesan-pesan radikal atau ekstremis. Ada dua kata yang sering jadi konten kicauan. Kata kunci terbanyak pertama ialah "kafir" dengan 5.173 kicauan, dan terbanyak kedua "komunis" sebanyak 995 kicauan dalam sebulan (https://tirto.id).

Pada bulan oktober lalu ada terjadi kasus yang miris terkait dengan intoleransi yang terjadi di dunia pendidikan, dimana ada salah seorang guru yang menyebarkan pesan untuk tidak memilih calon ketua osis yang tidak seiman. Selain itu berbagai macam tanggapan di media sosial pun semakin banyak menjadikan berita ini viral saat itu.

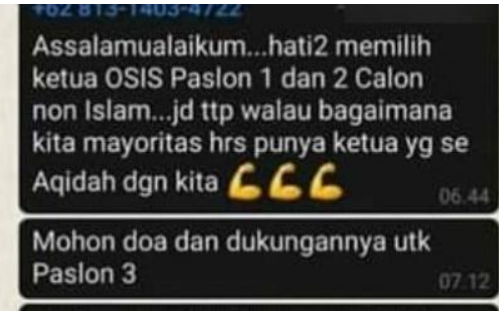

Gambar 1. Chat penyebar intoleransi

(sumber:antaranews.co.id)

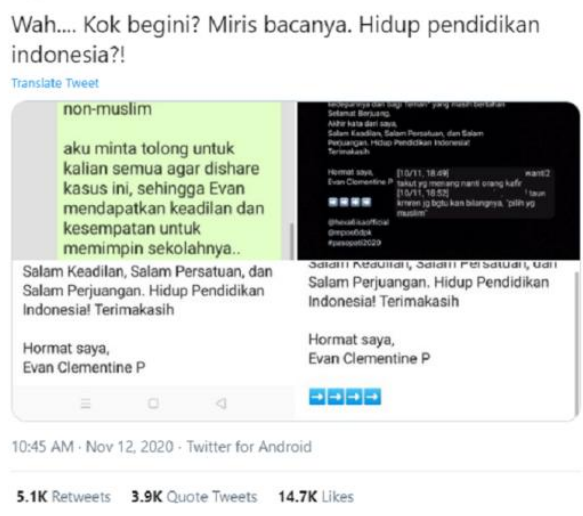

Gambar 2. Respon di media sosial (sumber: rir.co.id)

Pada dasarnnya isu intoleransi baik SARA/radikalisme cukup banyak dan sering terjadi apalagi dengan perkembangan jaman, orang sering sekali mendapatkan berita melalui media sosial yang belum tentu kebenaran langsung di bagikan/ di share ke orang lain. Hal tersebut juga berdasarkan hasil laporan aduan yang masuk Turnbackhoax.id yang dilakukan pada tahun 2017. Data pada gambar 3 dibawah ini menggambarkan bahwa aduan

\section{Paris Langkis}


yang tinggi adalah terkait dengan SARA/Kebencian, padahal dasar muncul sikap intoleransi bisa saja terjadi karena rasa benci terhadap suatu kelompok.

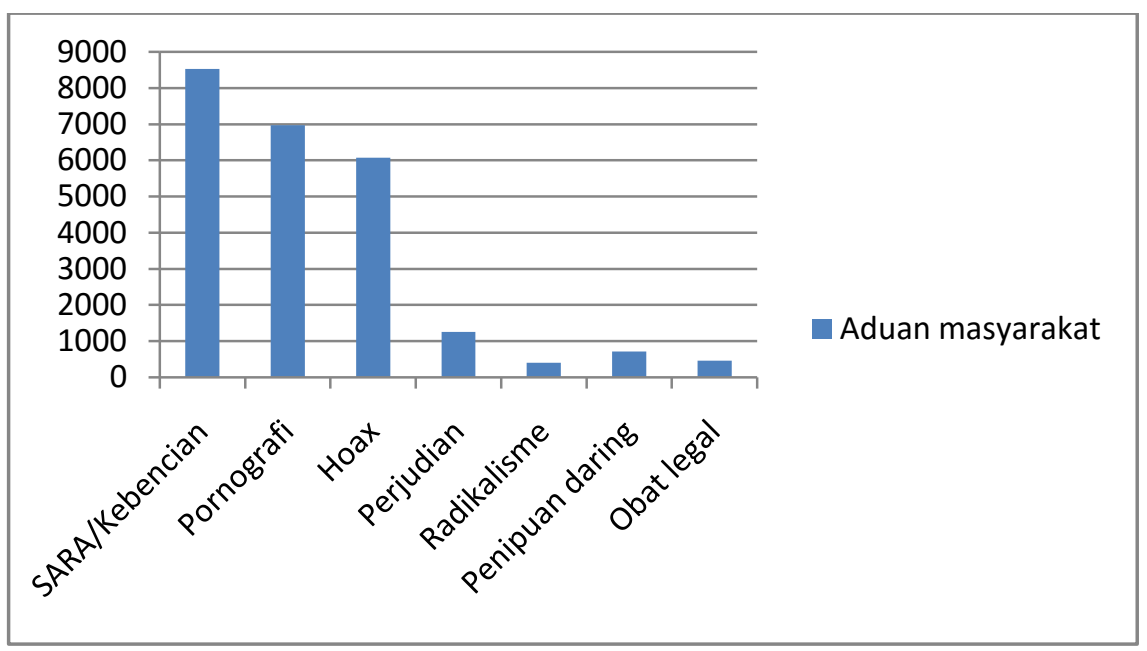

Gambar 3. Diagram aduan masyarakat (sumber turnbackhoax.id)

Kemudian adanya korelasi media sosial dengan intoleransi hal tersebut dari hasil penelitian yang dilakukan oleh Cahyo Pamungkas dari Peneliti dari Lembaga Ilmu Pengetahuan Indonesia menyebut media sosial memiliki peran yang penting dalam mendorong seseorang untuk bersikap intoleran. Berdasarkan penelitiannya, media sosial digunakan oleh orang yang memiliki tingkat fanatisme tinggi, dukungan terhadap sekularisasi yang rendah, spiritualitas keagamaan yang rendah, perasaan terancam dan ketidakpercayaan pada kelompok lain yang tinggi akan mendorong orang dengan identitas agama dan etnis yang kuat bertindak intoleran dan radikal (https://www.republika.co.id).

Namun, seperti pada hakikatnya bahwasanya media sosial akan memberikan dua dampak yakni negatif dan positif. Jika sebelumnya telah dijelaskan peran media sosial dalam menumbuhkan atau menyebarkan nilai intolernasi, tapi dibalik itu media sosial juga sangat berpeluang dalam meningkatkan atau mengintgrasikan masyarakat yang berbeda-beda dan akan menubuhkan nilai-nilai toleransi. Adapun peluang media sosial dalam menanmakn nilai toleransi diantaranya adalah: 1) Media sosial sebagai jembatan, perkembangan teknologi yang semakin maju, media sosial dapat dijadikan alat untuk menyebarkan nilai-nilai toleransi startegi tersebut akan menjadi efektif jika bekerjasama antarseluruh elemen masyarakat dari masyarakat biasa dan pemerintah. 2) Konten yang positif, berlandaskan pada penelitian yang dilakukan oleh Amrum Jarir (2017) terkait rublik opini Riau pos, maka dari itu masyarakat dapat memanfaatkan media sosial sebagai penyebar nilai-nilai toleransi melalui konten yang dibuat; 3) Perlunya selektif (filter), berita hoax dan penyebar kebencian di media sosial makin hari makin marak apalagi terkait toleransi, masyarakat harus selektif

\section{Paris Langkis}

Vol.1 Nomor 2, Maret 2021 
dalam memilih, membaca dan menyebarkannya. Masyarakat dituntut untuk kritis dalam memilih berita yang ada di media sosial.

Media sosial memiliki potensi dan peluang yang sangat besar dalam menyelesaikan masalah intoleran yang ada di masyarakat. Meskipun sebagaian besar media sosial adalah tempat untuk menyebarkan intoleransi tapi dibalik semua itu ada potensi besar. Kehidupan masyarakat saat ini apalagi di era disrupsi media sosial sudah seperti menjadi bagiannya yang tidak bisa lepas. Memilih konten, menyaring dan menyebarkan nilai-nilai toleransi dapat menjadi instrumen atau alat yang diperlukan dalam meningkatkan toleransi di masyarakat yang diharapkan dapat terciptanya kedamaian. Selain itu, kerjasama dalam hal ini juga sangat diperlukan dan penegak hukum juga harus kuat dalam menyelesaikan masalah intoleransi di media sosial.

\section{Analisis Resiliensi Pancasila di Era Disrupsi dalam Dilematis Media Sosial}

Era disrupsi membawa perubahan yang signifikan dalam kehidupan masyarakat, media sosial hadir diharapkan memberikan suatu intregrasi dalam masyarakat malah menimbulkan dilematis. Namun, hal tersebut sudah tidak asing lagi apalagi efek dari media sosial dapat menimbulkan dampak positif dan negatif. Dilematis yang terjadi pada media soosial justru dapat menggoyahkan ideologi pancasila. Pancasila yang diharapkan menjadi solusi atas permasalah justru malah terkana efek dari media sosial khususnya terkait isu intolernasi. Keberagaman juga menjadi karakter Indonesia seakan digoncangkan, dari lima sila yang ada di Pancasila dapat dijadikan penguatan, namun sebaliknya jika pancasila tidak memiliki resiliensi atau kekuatan/ketangguhan yang cukup baik makan akan berefek buruk pada keberagaman. Berikut penjelasannya:

1) Ketuhanan yang Maha Esa, pada sila pertama yang mengandung bahwa seluruh elemen masyarakat memiliki kepercayaan masing-masing, kasus intoleransi yang bertebaran di media sosial sangat bertentangan dengan sila pertama. Maka dari itu masyarakat harus memiliki sikap dan perilaku toleransi.

2) Kemanusian yang adil dan beradab, tidak sedikit masalah intoleransi akan berdampak pada keadilan pada golongan tertentu. Negara yang sudah menjamin warga negaranya hidup dengan tenang, dengan adanya intoleransi akan berdampak pada golongan tertentu apalagi bagi masyarakat minoritas, sebab tidak sedikit pula dampak intoleransi dituduhkan pada minoritas, hal yang parah bisa berakibat pada hilangnya rasa kemanusiaan (teroris, radikalisme, hujatan)

3) Persatuan Indonesia, pada sila ini sudah sangat jelas bahwasanya intoleransi sangat bertentanan dengan ideologi pancasila. Intoleransi akan berdampak pada perpecahan antar golongan. Namun, dengan hadirnya media sosial ujaran kebencian seakan perasatuan Indonesia sedang diuji. Namun, bisa jadi hadirnya pancasila dapat menciptakan

\section{Paris Langkis}

Vol.1 Nomor 2, Maret 2021 
persatuan dan intregrasi pada masyarakat jika menggunakan atau memanfaatkan media sosial dengan bijak.

4) Kerakyatan yang dipimpin oleh hikmat kebijaksanaan dalam permusyawaratann/perwakilan, pada sila keempat pun sama dengan sila sebelumnya bahwa intoleransi sangat bertentangan dengan pancasila. Sikap bijaksana yang dimiliki oleh pemimpin akan mempengaruhi dalam mengatasi masalah intoleran saat ini, namun ada juga sebaliknya seorang pemimpin yang menyebarkan nilai intoleransi salah satu fenomena yang terkenal adalah saat isu intoleransi dalam pemilihan umum di Jakarta.

5) Keadilan sosial bagi seluruh rakyat Indoensia, sudah barang tentu intoleransi akan menimbulkan ketidakadilan dalam masyarakat. Hal itu juga bertentangan dengan sila kelima ini, negara sudah menjamin keadilan bagi seluruh masyarakat tanpa memandang latar belakang, namun dengan adanya intoleransi yang ada di masyarakat keadilan tersebut akan sangat sulit untuk dicapai.

Peran pemerintah dan tokoh agama sangat berperan dalam menanggapi atau menyelesaikan kasus intoleransi, namun sangat disayangkan berdasarkan hasil survei yang dilakukan oleh Litbang Kompas menjelaskan bahwa kinerja pemerintah belum memadai sekitar $67,2 \%$, sudah memadai hanya $31,2 \%$ sisanya tidak menjawab, hal tersebut sangat disayangkan kinerja pemrintah yang diharapkan masayrakat untuk menyelesaikan namun belum berjalan dengan baik. Berikut diagramnya:

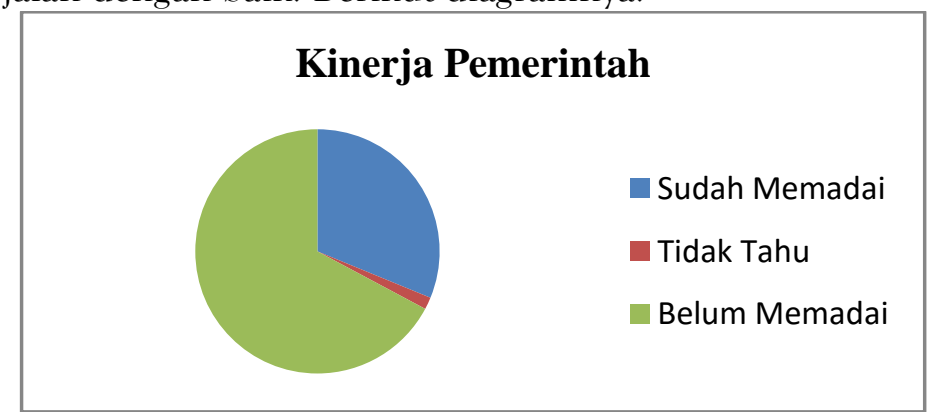

Gambar 4. Diagram Kinerja Pemerintah dalam kasus intoleransi (sumber: Litbang Kompas)

Ketangguhan dan kekuatan pancasila saat ini sedang diuji, perkembangan jaman yang memasuki era disrupsi yang seakan menciptakan ruang tanpa batas menjadi sulit dikontrol. Media sosial yang sudah sangat dekat dengan kehidupan masyarakat akan menjadi seperti dua belah mata pisau. Jika dimanfaatkan dengan bijak akan mengguhkan pancasila tapi sebaliknya jika kurang bijak justru menjadi ancaman bagi ideologi pancasila itu sendiri.

\section{KESIMPULAN}

Pancasila sebagai ideologi bangsa Indonesia diharapkan dapat menyelesaikan masalah intoleransi. Media sosial yang sudah melekat dalam 
kehidupan masyarakat seakan menjadi dilematis, dapat memberi dampak positif dan negatif bagi Pancasila. Saat ini pancasila sedang diujia keteguhan/kekuatannya. Meskipun media sosial yang dapat mengoncakan pancasila (seperti penyebaran hoax, ujaran kebencian terhadap perbedaan terlebih kaum minoritas), namun dibalik itu sendiri media sosial justru dapat menjadi kekuatan untuk mengintregrasikan masyarakat agar tercipta lingkungan yang toleran yakni sebagai alat dengan menyebarkan berita baik, konten yang positif terkait toleransi. Perlunya kerjasama yang baik dan pengoptimalan peran pemerintah dalam menyelesaikan isu toleransi ini.

\section{E. UCAPAN TERIMAKASIH}

Penulis mengucapkan terima kasih kepada Seluruh pihak yang terlibat dqalam penulisan Artikel iniserta semua pihak yang mendukung baik secara materi ataupun nonmateri sehingga tulisan ini dapat diselesaikan dengan baik.

\section{DAFTAR PUSTAKA}

Jurnal

Amrun, Jarir dan Khairiah. 2017. Nilai-nilai Toleransi di Media Massa (Studi Terhadap Rubrik Opini Riau Pos). TOLERANSI : Media Komunikasi Umat Beragama. Vol. 9, No. 2, Juli- Desember 2017.

Cholil, Ali Fikri. 2019. Pengaruh Globalisasi dan Era Disrupsi Terhadap Pendidikan dan Nilai-nilai Islam. Sukma: Jurnal Pendidikan. ISSN: 25485105 (p), 2597-9590 (e) volume 3 issue 1, Jan-Jun 2019. https://doi.org/10.32533/03106.2019.

Digdoyo, Eko. 2018. Kajian Isu Toleransi Beragama, Budaya, dan Tanggungjawab Sosial Media. JPK: Jurnal Pancasila dan Kewarganegaraan, Vol. 3, No. 1, Januari 2018 ISSN 2527-7057 (Electronic), ISSN 2545-2683 (Print)

Kinseng, Rilus A. 2019. Resiliensi Sosial dari Perspektif Sosiologi: Konsep dan Aplikasinya Pada Komunitas Nelayan Kecil. TALENTA Universitas Sumatera Utara di Konferensi Nasional Sosiologi VIII 2019. P-ISSN: 2654-7058, e- ISSN: 2654-7066, DOI: 10.32734/lwsa.v2i1.623

Muslimin, Hussein. 2016. Tantantan Terhadap Pancasila sebagai Ideologi dan Dasar Negara Pasca Reformasi. Jurnal Cakrawala Hukum, Vol. 7, Juni 2016, hlm. 30-38 http://jurnal.unmer.ac.id/index.php/jch.

Ohoitimur, Johanis. 2018. Disrupsi: Tantangan bagi Perkembangan Ilmu Pengetahuan dan Peluang bagi Lembaga Pendidikan Tinggi. RESPONS UNIKA ATMA JAYA, Jakarta, volume 23 no. 02. 02 (2018): 143-166.

\section{Buku}

\section{Paris Langkis}

Vol.1 Nomor 2, Maret 2021 
Azhar, S. (2018). Distruption Era. Jakarta: PT Asuransi Tugu Pratama Indonesia Tbk.

Moloeng, Lexy J. 2011. Metodologi Penelitian Kualitatif. Bandung: Remaja Rosda Karya.

Parekh, B. 2010. Rethinking Multiculturism. Yogyakarta: Penerbit Kanisius.

\section{Peraturan/Undang-undang}

Departemen Pendidikan Nasional (Depdiknas). 2008. Kamus Besar Bahasa Indonesia Pusat Bahasa Edisi Keempat. Jakarta: Departemen Pendidikan Nasional.

\section{Naskah Internet}

Hidayat, Irwan. 2019. Tantangan Masyarakat di Era Disrupsi. Diakses di https://radarjember.jawapos.com/opini/07/12/2019/tantanganmasyarakat-di-era-disrupsi// pada tanggal 2 Desember 2020.

Kanal Opini. 2020. Pancasila di Era Digital, Globalisasi dan Milenial. Diakess di https://www.matakalteng.com/kolom/opini/2020/01/11/pancasila-diera-digital-globalisasi-dan-millenial pada tanggal 2 Desember 2020.

Khulumudin, Ikhsan. 2011. Landasan Filosofis Pancasila. Tugas Akhir Sekolah Tinggi Manajemen Informatika dan Komputer. Yogyakarta.

Kompas. 2017. Kinerja Pemerintah dalam Menangani Maslaah Intoleransi.

Nashruallah, Nashih. 2018. Peneliti LIPI Ungkap Korelasi Media Sosial dan Intoleransi. Diakses di https://www.republika.co.id/berita/duniaislam/islam-nusantara/18/12/05/pj8toz320-peneliti-lipi-ungkap-korelasimedia-sosial-dan-intoleransi pada tanggal 3 Desember 2020.

Social Indonesian Digital Report. 2020. Data Tren Internet dan Media Sosial Indonesia menurut Hootsuite diakses di https://andi.link/hootsuite-weare-social-indonesian-digital-report-2020/ pada tanggal 2 Desember 2020.

Supadjar, Damardjati, dkk. 1996. Landasan Pengembangan Filsafat Pancasila. Jurnal Filsafat, Desember 2996.

Tirto.Id. 2017. Survei: Pesan Intoleransi Bertebaran di Media Sosial. Diakses di https://tirto.id/survei-pesan-intoleransi-bertebaran-di-media-sosial-cfeY pada tanggal 2 Desember 2020.

Universitas Pasundan. 2012. Apa itu Sosial Media. Diakes di http://www.unpas.ac.id/apa-itu-sosial-media/ pada tanggal 2 Desember 2020.

Very. 2020. Arya Bima: Nilai-nilai Pancasila Terkoyak di Era Disrupsi Teknologi. Diakses di https://indonews.id/artikel/30175/Arya-Bima-Nilai-nilaiPancasila-Terkoyak-di-Era-Disrupsi-Teknologi/ pada tanggal 2 Desember 2020.

\section{Paris Langkis}

Vol.1 Nomor 2, Maret 2021 